\title{
METÓDA MOMENTOVÉHO POZOROVANIA - EFEKTÍVNA FORMA ČASOVEJ ŠTÚDIE
}

\author{
Pavel Kaštánek*
}

\section{Úvod}

V konkurenčnom prostredí poštových podnikatel'ských subjektov je dôsledné využívanie pracovného času dôležitým predpokladom zvyšovania efektívnosti a produktivity práce. Napriek niekedy protichodným názorom o potrebe normovania práce je normovanie práce aj $\mathrm{v}$ súčasnosti jedným $\mathrm{z}$ účinných prostriedkov účelného hospodárenia s pracovným časom.

\section{Časové štúdie}

Významným predpokladom uplatňovania normovania práce je využívanie časových štúdií. Časové štúdie sú podkladom pre tvorbu, zmeny a kontrolu plnenia noriem spotreby práce a ich úlohou je poskytovat' informácie predovšetkým o:

- časovom rozložení pracovných činností,

- trvaní pracovných činností,

- spotrebe pracovného času,

- príčinách vzniku časových strát.

V poštových podnikoch je vhodné uplatňovat' najmä nasledovné druhy časových štúdií:

- snímky pracovného dňa,

- snímky pracovných operácií,

- momentové pozorovanie.

Snímkou pracovného dňa rozumieme metódu nepretržitého pozorovania, merania, zaznamenávania i hodnotenia celkovej spotreby pracovného času na pracovisku počas trvania snímky (t.j. počas celej zmeny). Záznam priebehu práce sa môže robit' u jedného alebo niekol'kých zamestnancov súčasne, na jednom alebo viacerých pracoviskách. Touto snímkou zist'ujeme predovšetkým bilanciu skutočnej spotreby pracovného času, t.j. jednotlivé druhy pracovného času a dížku ich trvania. Získané údaje je potrebné využit' najmä tam, kde sa vyskytli časové straty. Zistenie vel'kosti a príčin časových strát umožňuje vypracovat' návrh opatrení na ich odstránenie, resp. ich redukciu. Snímky súčasne poskytujú podkladový materiál na vypracovanie bilancie normatívnej spotreby času, ktorej súčast'ou sú normatívy času na prípravu a dokončenie, normatívy na obsluhu, na prirodzené potreby a oddych.

\footnotetext{
* Ing. Pavel Kaštánek, Žilinská univerzita v Žiline, Fakulta prevádzky a ekonomiky dopravy a spojov, Katedra Spojov, Univerzitná 1, 01026 Žilina, Slovenská republika, tel.: +421 41513 3122, E-mail: pavel.kastanek@fpedas.uniza.sk
} 
Snímkovaním práce zamestnancov môžeme sledovat' ich pracovné postupy a skladbu ich pracovného času, čo umožňuje získat' materiál na určenie vhodných pracovných postupov. Snímka je tiež účinná metóda na stanovenie počtu zamestnancov a môže slúžit' aj na overenie splnitel'nosti výkonových noriem, resp. príčin ich neplnenia.

Pri vyhodnotení snímok pracovného dňa je možné sledovat' napríklad ukazovatele zamestnanosti zamestnanca, ukazovatel' percentuálneho podielu zbytočnej spotreby času zapríčinenej zamestnancom, resp. zapríčinenej technickými a organizačnými nedostatkami v čase pracovnej zmeny, ukazovatele možného zvýšenia produktivity práce po odstránení zbytočnej spotreby času spôsobenej zamestnancom, resp. spôsobenej technickoorganizačnými nedostatkami a ukazovatel' (celkové percento) možného zvýšenia produktivity práce.

Snímka pracovnej operácie je metódou prieskumu pracovného času spotrebovaného zamestnancom na vykonanie určitej opakovanej operácie. Zatial' čo snímka pracovného dňa sa zameriava na prieskum pracovného času vynaloženého v priebehu celej pracovnej zmeny, predmetom snímky operácie je spotreba pracovného času pripadajúceho na jednotlivé prvky pracovnej operácie. Účelom snímky pracovnej operácie je:

- získat' podkladový materiál pre tvorbu normatívov času, alebo noriem času v prípade, že nie sú vypracované normatívy času, alebo v prípade, že sú už vypracované, ale došlo k zmene pracovného postupu, organizácie práce a pod.,

- rozborom práce vytvorit' podklady na zlepšenie technického a organizačného zabezpečenia práce a na posúdenie účelnosti pracovného postupu.

Metóda momentového pozorovania je metódou prerušovaného prieskumu času spotrebovaného v priebehu pracovného dňa. Ide o metódu menej prácnu a nákladnú a teda jej využitel'nost' je v poštových podnikoch značná a pestrá. Metóda spočíva v náhodne zaznamenanom vel'kom počte pozorovaní v nepravidelných časových výskytoch a vo výpočtovo - štatistickom pozorovaní obsahu skúmaných dejov s vopred určenou toleranciou. V podstate ide o výberovú metódu zist'ovania vel'kosti rozličných kategórií spotreby času v priebehu konkrétneho pracovného, technologického, alebo celého výrobného procesu, prípadne niekol'kých rozdielnych procesov založených na štatistickom zist'ovaní výskytu pozorovaných dejov $\mathrm{v}$ tol'kých okamihoch a objektoch pozorovania, ako to zodpovedá požadovanej miere spol'ahlivosti výsledkov. Metódou teda môžeme zistit' podiel jednotlivých kategórií času na pracovnej zmene, najmä času práce, času nečinnosti, strát a ich príčiny. Tzn., že je možné zistit' využitie fondu pracovného času, resp. využitie výrobných, dopravných a iných zariadení. Metódu je možné, podobne ako snímku pracovného dňa, využit' na rozbor organizácie práce, čím sa získajú podklady na odstránenie zistených nedostatkov.

Spôsob metódy momentového pozorovania spočíva $\mathrm{v}$ tom, že pozorovatel' prechádza $\mathrm{v}$ nepravidelných časových úsekoch od jedného zamestnanca (zariadenia) k druhému a zaznamenáva to, čo v danom momente robí. Obchôdzky sa vykonávajú nepravidelne podl’a časového plánu, pričom musí byt' moment každého opakovaného pozorovania náhodný. To znamená, že začiatok každej obchôdzky sa musí zvolit' náhodne. Dôležitým činitel'om pri určovaní zložiek času na skúmanie je ich počet. Čím časovo kratšiu zložku zmeny chceme v priebehu skúmania zistit', tým väčší počet pozorovaní musíme vykonat' na dosiahnutie primeranej relatívnej chyby výsledku. Počet potrebných meraní závisí od predpokladanej početnosti výskytu základného sledovaného deja a od vyžadovanej presnosti výsledkov. Pri určovaní počtov momentových záznamov je možné využit’ tzv. Tippetov vzorec: 


$$
n=\frac{4(1-p)}{p \cdot y^{2}}
$$

kde: $\mathrm{n}$ - potrebný počet meraní,

$\mathrm{p}$ - koeficient predpokladaného podielu sledovaného základného deja v zmene,

y - hodnota prípustnej relatívnej chyby určovaná podl'a ciel'a pozorovania.

Údaje sa získavajú prostredníctvom pozorovatel'a, ktorý začne pozorovat' deje v čase určenom prvým intervalom. V čase príchodu na pozorovacie stanovisko zistí charakter činnosti a zaznačí ju na príslušné tlačivo značkou alebo kódom. Na skúmanie nie je potrebný chronometer.

Vyhodnotenie sa vykonáva na tlačivách denných záznamov, kde sa sčítajú všetky zaznačené výskyty pri jednotlivých objektoch a ich činnostiach. Súčtom vyjadrený počet výskytov sa prevedie na množstvo výskytu sledovanej činnosti v percentách.

Metódou momentového pozorovania možno v niektorých prípadoch výhodne nahradit' snímky pracovného dňa, napríklad pri orientácii časovej štúdie na sledovanie a vyhodnocovanie ukazovatel'ov zamestnanosti a časových strát. Pre tento účel je však nevyhnutné vykonat' prevod momentov na dížku času.

Výhody metódy momentového pozorovania teda sú:

- nižšie náklady na pozorovanie,

- prácnost' predstavuje polovicu až tretinu prácnosti kontinuitných metód,

- možnost' prerušenia pozorovania v ktoromkol'vek čase,

- pozorovatel' môže merat' súčasne viac pracovísk, pričom môže íst' o rovnorodé aj rôznorodé pracoviská,

- meranie možno uskutočnit' v dlhšom období, a tak je možné objavit' rôzne náhodné činitele pôsobiace na pracovný proces, čo je pri kontinuitnom meraní nepravdepodobné, pretože sa uskutočňuje v relatívne kratšom časovom intervale,

- pozorovaní zamestnanci priaznivejšie prijímajú pozorovanie ako pri iných metódach.

Hlavné nedostatky tejto metódy sú:

- nie je možné zist'ovat' čas postupných činností v pracovnej zmene,

- metóda je neefektívna pre sledovanie práce na pracoviskách rozmiestnených na príliš vel'kom priestore,

- pre menej významné činnosti je potrebný vel'ký počet meraní.

Pri aplikácii metódy momentového pozorovania sa dosiahnu objektívne výsledky ak sa dodržia tieto etapy pozorovania:

- príprava na pozorovanie,

- vlastné zist'ovanie údajov,

- vyhodnotenie pozorovania.

Dôsledná príprava je podmienkou úspešného výsledku praktickej aplikácie tejto metódy. Najskôr je potrebné si ujasnit' ciel', ktorý sa bude sledovat' a vymedzit' objekty štúdia. Ciel'om pozorovania môže byt' napr. zistit' iba podiel času práce a času nečinnosti v pracovnej zmene jedného alebo viacerých zamestnancov alebo zariadení, alebo poznat' podiel času zmenovej práce, času zmenových všeobecne nevyhnutných prestávok a času podmienečne potrebných prestávok, prípadne iné členenie času zmeny, a to podl’a zámerov, ktoré štúdiom sledujeme. 
Objektom štúdia môžu byt' zariadenia, rôzne kategórie zamestnancov, vozidlá a pod. Pre vlastné uplatnenie metódy je dôležité, či pôjde o štúdium stacionárnych alebo mobilných objektov.

V prípade skúmania stabilných pracovísk je vhodné vypracovat' stručný náčrt priestorového rozloženia pozorovaných objektov, označit' v ňom trasy možných obchôdzok medzi objektmi a označit' ich poradovými číslami.

Pri skúmaní mobilných pracovísk je potrebné aby trasy navrhnutých obchôdzok v maximálnej miere pretínali známe alebo predpokladané trasy mobilných objektov, pretože pri stretnutí pozorovatel'a na trase obchôdzky s mobilným objektom vzniká moment záznamu deja mobilného objektu.

Pri určovaní sledovaných zložiek času je základným časovým modulom pre výpočty celková čas pracovnej zmeny. Určené zložky času zmeny, ktoré sú predmetom skúmania, musia vo svojom súčte zodpovedat' času zmeny. To znamená, že v priebehu skúmania nesmie vzniknút' situácia, v ktorej by nejaká v náhodnom momente zistená činnost' podl'a jej charakteru nebolo možné zaradit' do niektorej vopred určenej charakteristickej skupiny zložiek času.

Pri určovaní zložiek času na skúmanie je dôležitým rozhodnutím ich počet, ktorý je teoreticky neobmedzený. Prakticky sú však obmedzenia dané prácnost'ou skúmania. Ako už bolo vyššie uvedené čím časovo alebo percentuálne menšiu zložku času zmeny chceme v priebehu zmeny skúmania zistit', tým väčší počet pozorovaní musíme vykonat' na dosiahnutie zodpovedajúcej relatívnej chyby výsledku.

Vyhodnotenie výsledkov pozorovania spočíva $\mathrm{v}$ tom, že súčet výskytov príslušného deja sa prevedie na percentuálne množstvá výskytu sledovaných činností pri konkrétnom objekte alebo skupine objektov, a to podl'a vzt'ahu:

$$
\% p=\frac{N_{p}}{N_{c}} .100
$$

kde: \%p - percento výskytu príslušnej zložky času z celkového času zmeny,

$\mathrm{N}_{\mathrm{p}}$ - počet výskytov príslušnej zložky času,

$\mathrm{N}_{\mathrm{c}}-$ celkový počet momentov pri objekte alebo pri skupine objektov.

V priebehu skúmania, najlepšie podl'a denných výsledkov je potrebné opät' prepočítat' hodnotu n (potrebný počet pozorovaní), pretože do uvedeného Tippetovho vzorca bola dosadená hodnota $\mathrm{p}$ iba odhadom, čím sme zistili len približný počet momentov pre celý priebeh skúmania. V priebehu skúmania môžeme dennou kontrolou zistit', že na zabezpečenie výslednej tolerancie konečných hodnôt nie je nevyhnutné uskutočnit' plánovaný počet momentov, alebo naopak, že priebežné hodnoty potvrdia, že predpokladaný počet moment je nedostatočný. O tom, či sa dosiahli príslušné tolerancie pri jednotlivých zložkách času sa môžeme presvedčit' výpočtom podl'a vzt'ahu:

$$
y=\sqrt{\frac{4(1-p)}{N_{c} \cdot p}}
$$

kde: y- tolerancia zvolenej zložky času.

\section{Záver}


Článok je orientovaný na prezentáciu možností využitia časových štúdií, predovšetkým momentového pozorovania, ktorej z dôvodu deklarovanej výhodnosti je venovaná podstatná čast' textu. Využitie uvedených metód v praxi poštových i telekomunikačných podnikatel'ských subjektov môže aj v súčasnom období pomôct' zvýšit' efektívnost' hospodárenia s časom a tým aj rentabilitu podniku.

\section{Literatúra}

[1] LHOTSKÝ, J.: Organizace a normování práce v podniku, ASPI, Praha, 2005, 104 str., ISBN 80-7357-095-5

[2] KAŠTÁNEK, P., ROVŇANOVÁ, T., ŠTOFKOVÁ, J.: Ekonomika spojového podniku I, EDIS, Žilina, 1994, 149 str., ISBN 80-7100-189-9

[3] ŠTOFKOVÁ, J., ROSTAŠOVÁ, M., ŠTOFKO, S., KAŠTÁNEK, P.: Financie, EDIS, Žilina, 2005, 212 str., ISBN 80-8070-501-1 